UDC $1: 316$

LBC 87.6

\title{
ON THE EPISTEMOLOGICAL FOUNDATIONS OF WAR AS A SOCIAL PHENOMENON
}

\author{
Alexey N. Gulevsky \\ Volgograd Academy of the Ministry of Internal Affairs of the Russian Federation, Volgograd, Russian Federation \\ Yuri P. Doronin \\ Volgograd Academy of the Ministry of Internal Affairs of the Russian Federation, Volgograd, Russian Federation
}

\begin{abstract}
The article analyzes the epistemological foundations of the war. According to the authors, the idea of war is the result of previous cognitive and mental activity of a person. War as a form of struggle involves the use of special knowledge and thinking abilities. A field of specialized knowledge appeared, called the art of war, and then military science. War turned out to be one of the most important spheres of human activity, requiring high achievements in the field of science. Abstract thinking made it possible, by introducing generalized concepts and images ("enemy", "homeland", "good", "evil", "bravery", etc.), to create a categorical field that allows waging a war for certain generalized interests that differ from the private ones. War has a rational motive, goal, methods and means, process, result, and implies a reflexive understanding of the warfare results. Planning and waging war requires a person to search for logical connections, identify patterns and cause-and-effect relationships when solving complex creative tasks and organizing activities in a changing environment. The belligerents strive for the efficient use of funds and the conclusion of peace on reasonable terms. In this sense, war can be seen as a form of a rational solution to social problems.
\end{abstract}

Key words: war, armed struggle, philosophy of war, knowledge, military theory, truth.

УДК $1: 316$

ББК 87.6

\section{О ГНОСЕОЛОГИЧЕСКИХ ОСНОВАНИЯХ ВОЙНЫ КАК СОЦИАЛЬНОГО ЯВЛЕНИЯ}

\author{
Алексей Николаевич Гулевский \\ Волгоградская академия МВД России, г. Волгоград, Российская Федерация \\ Юрий Петрович Доронин \\ Волгоградская академия МВД России, г. Волгоград, Российская Федерация
}

Аннотация. В статье осуществлен анализ гносеологических оснований войны. По мнению авторов,
идея войны представляет собой результат предшествующей познавательной и мыслительной деятельности
человека. Война как форма борьбы предполагает использование особых знаний и мыслительных способ-
ностей. Появилась область специализированных знаний, называемая искусством войны, а затем военной
наукой. Война оказалась одной из важнейших сфер деятельности человека, требующей высоких достиже-
ний в области науки. Абстрактное мышление позволило при помощи введения обобщенных понятий и
образов («враг», «родина», «добро», «зло», «храбрость» и др.) создать категориальное поле, позволяю-
щее вести войну за некие обобщенные интересы, отличные от интересов частных. Исследуемое явление
имеет рациональный мотив, цель, методы и средства, процесс, результат, предполагает рефлексивное ос-
мысление итогов ведения войны. Планирование и ведение войны требует от человека поиска логических
связей, выявления закономерностей и причинно-следственных связей при решении сложных творческих
задач и организации деятельности в условиях меняющейся обстановки. Воюющие стремятся к эффективно- 
му использованию средств и заключению мира на разумных условиях. В этом смысле войну можно рассматривать как одну из форм рационального решения социальных проблем.

Ключевые слова: война, вооруженная борьба, философия войны, знание, военная теория, истина.

На протяжении последних нескольких лет тема войны стала одной из центральных в многочисленных дискуссиях как в рамках научного дискурса, так и в популярном медийном пространстве. В мире продолжают расти конфронтационные настроения. Надежды на то, что крушение коммунистической идеологии и победа либерализма приведут вкупе с ядерным оружием к долгожданному «вечному миру», о котором писал немецкий философ И. Кант [Кант 1966, 259], не оправдались. На смену, а точнее, в дополнение к идеологическим противоречиям как причине конфликтов пришли противоречия экономические, политические, культурные. Оказалось, что идеологические расхождения - лишь повод для противостояния и устранение этого повода не обеспечивает мир автоматически, а попытки сдерживания имеющегося ядерного оружия приводят к новым виткам гонки вооружений.

Возникает вопрос о том, что же двигает разумное человечество в горнило весьма опасного для существования противостояния? Существует множество попыток объяснения исторического, культурологического, философского осмысления феномена войны. Философское осмысление какого-либо феномена может выражаться, во-первых, в определенной позиции и определенном подходе исследователя, предполагающем использование специальных философских методов при анализе явления (феноменологический, герменевтический, диалектический, метафизический, материалистический, идеалистический и др.). Во-вторых, философское осмысление может предполагать поиск фундаментальных оснований явления - того, что предопределяет его появление и делает феномен тем, что он есть. Такое осмысление предполагает уже высокий уровень абстрагирования, поиск предельных смыслов и ключевых детерминаций. В рамках темы исследования речь идет об онтологических, гносеологических, антропологических, аксиологических основаниях войны как социального феномена.

Анализ как классических, так и современных работ доказывает, что осмысление войны в контексте ее философских оснований уже предпринималось, хотя не всегда квалифицировалось подобным образом. Гераклит видит основанием войны энергию, силу, огонь как метафизические начала. Платон обнаруживает два основания войны: одно из них вожделеющее, материальное начало, связанное с испорченностью общества, другое разумное, упорядоченное, целесообразное, идеальное воплощенное в идее блага [Платон 1994]. Августин Блаженный видит основанием войны Божественный промысел и свободу, волю человека, подчиненную этому промыслу [Августин 1998]. Г. Гроций видит основание войны в области права. Война выступает как проявление естественного права - в случае, если чьи-то права попраны, или, наоборот, кто-то считает, что имеет право на что-либо [Гроций 1994]. Н. Макиавелли и К. Клаузевиц основания войны укореняли в политике, считая ее главной причиной стремление к власти [Макиавелли 1939]. В.С. Соловьев основание войны усматривает в наличии в обществе духовных болезней [Соловьев 2011]. И.А. Ильин рассуждает о правомерности использования силы для достижения идеалов справедливости [Ильин 2014]. М. ван Кревельд полагает, что в основе войны как традиционного занятия мужчин лежат такие закрепившиеся в культуре социально-психологические феномены, как чувство справедливости, религиозность, тщеславие [Кревельд 2005]. Й. Хейзинга видит в войне игровую культурную основу. Войну и игру объединяют наличие правил и состязательность [Хейзинга 2011]. Э. Тоффлер обнаруживает в войне экономико-технологическую основу [Тоффлер 2005]. Х. Хофмайстер полагает, что война - не инструмент реализации политики, но проявление ее бессилия, она есть «невозможная возможность», ее основание - в переживании свободы, позволяющем выйти за пределы необходимости [Хофмайстер 2006]. Н.Н. Герасимов анализирует образ войны в эпоху глобализации [Герасимов 2019]. Нами, в свою очередь, был осуществлен анализ онтологических и антропологических оснований войны [Гулевский, 
Гулевская 2012, 16-19; Гулевский 2014, 9-12; Гулевский, Гулевская, Доронин 2018, 69-76].

Задача данной статьи - выявить и проанализировать гносеологические основания войны как социального феномена, то есть установить предельные теоретико-познавательные основания, которые в качестве составляющих познавательного и рефлексивного отношения к миру делают возможным возникновение такого феномена, как война. Хотим особо обратить внимание, что мы не ставим перед собой задачу создать гносеологию войны - это отдельный и достаточно объемный труд, предполагающий исследование всего множества подходов и теоретических выкладок относительно исследуемого нами феномена. Изучение теорий войны - достаточно распространенная научная проблематика. Ее решению посвящены исследования А.Е. Снесарева [Снесарев 2013], Б.Г. Лиддел Гарта [Лиддел Гарт 2003], И.М. Попова, М.М. Хамзатова [Попов, Хамзатов 2016], А.А. Кокошина [Кокошин 2016], В.И. Слипченко и др. Однако гносеологические основания войны практически не выявлялись и не анализировались, поэтому их изучение заполняет важную исследовательскую нишу в дискурсе войны.

Войну ведут только люди. Среди животных мы встречаем борьбу, противостояние, агрессию, которые, как правило, являются следствием ряда биологических факторов и реализацией реакции «бей или беги», но только у людей эти реакции становятся биологической основой пролонгированных вооруженных противостояний. Следовательно, человеку присуще нечто преобразующее сиюминутные биологические реакции в длительные ответные взаимодействия. Человеку присуще сознание как особая форма отражения действительности, и одним из проявлений сознательного отношения человека к миру является его способность рефлексировать по поводу происходящего, выстраивать идеальные планы деятельности и общения, создавать знаково-символические системы, опосредующие взаимодействие человека с миром и другими людьми в процессе синтеза различных контекстов опыта. Эти способности мы и можем охарактеризовать как процесс познания человеком мира, формирование особенного, «знаниевого» к нему отношения. Указанная способность приобретать и использовать знание о мире в полной мере проявляется в процессе выстраивания рационального познания, в процессе формирования рациональности, которую мы вслед за Е.Ю. Леонтьевой определяем как «особую умопостигаемость объективно общего, своеобразную размерность сознательной деятельности, позволяющую постигать внутреннюю логику бытия» [Леонтьева 2003].

На раннем этапе развития у человека преобладает чувственно-образное познание и мифологическое мировоззрение. Переход к понятийному (объективно-общему) мышлению свидетельствует об изменении отношения человека к миру. Человек перестает видеть в природе нечто особенное, индивидуальное, неповторимое, одушевленное. Взаимодействуя с природой, человек выявляет некие общие свойства предметов или живых существ, что приводит к тому, что они становятся для него объектами, лишенными персональных, конкретных, индивидуальных качеств. Чем активнее шел этот процесс, тем больше человек воспринимал природу как объект для манипуляций. В этом и проявлялось противопоставление человеком себя природе, а затем и другим людям. Так, в иноплеменниках он научился видеть не конкретных людей с их индивидуальными качествами и особенностями, а абстрактную совокупность сходных, взаимозаменяемых врагов. Подобно тому, как животные, на которых велась охота, воспринимались как мало отличимые друг от друга, как обобщенная цель, так и люди (противники, представители других племен, народов) теряли свои индивидуальные черты, обретая обобщенные образы чужеземцев, превращаясь в абстрактную массу врагов, наделяемых абстрактными, как правило, негативными качествами. Так, уже древние греки и римляне называли всех чужеземцев общим понятием варвары. Во всех войнах солдаты давали своим противникам некие обобщенные имена: «Фрицы», «Иваны», «Джерри», «Томми», «Янки», «Гуки» и проч. Для того чтобы убивать других людей, с которыми ничем лично не связан и которые не причинили человеку персонально никакого вреда, нужно абстрагироваться от их конкретного восприятия и иметь некий обобщенный образ врага с 
приданием ему общей уничижительной психологической окраски.

Война представляет собой коллективную форму борьбы, где противник является временным и случайным. Сам воин должен ощущать себя частью общего коллектива, выполняющего общую задачу. Кроме абстрактного понятия «врага» возникает ряд других абстрактных понятий: «родина», «боевые товарищи», «храбрость» и прочее. Таким образом, абстрагирование, способность к понятийному абстрактному мышлению как важнейшая составляющая нашего умопостижения и познания мира может рассматриваться как гносеологическое основание феномена войны. «Принцип современного мира, мысль и всеобщее, придал храбрости высшую форму, в которой ее проявление представляется более механичным и делом не данного особенного лица, а членов целого, так же как и сама храбрость представляется вообще направленной не против отдельного лица, а против враждебного целого, и, таким образом, личное мужество являет себя как неличное. Поэтому данный принцип изобрел огнестрельное оружие, и неслучайное изобретение этого оружия превратило чисто личный характер храбрости в характер более абстрактный» [Гегель 1990].

Однако кроме возможности формирования абстракций в виде врага, родины, боевых товарищей и т. д. рациональность мышления проявляется в реализации размерной сознательной деятельности, следствием которой становится способность к выстраиванию логических цепочек и доказательств. Ограниченная во времени реакция «бей или беги»удел животных и выражение животного начала в человеке. Социальное в человеке проявляется тогда, когда он способен выстроить стратегию и тактику уже пролонгированных «бей» или «беги», что предполагает построение идеальной целенаправленной схемы деятельности с учетом логических и причинноследственных связей.

Осознание того, что смерть одних людей может быть полезной для других, а страх перед смертью у одних людей может принести пользу другим, привело к возникновению идеи войны как вида целесообразной разумной деятельности. Аристотель в своей «Политике» верно провел параллель между вой- ной и охотой, видом хозяйственной деятельности, где целью становились люди, часть которых хотя и склонна к подчинению, но сопротивляется этому, а потому их нужно укротить, сделав рабами, для чего они по своей природе и предназначены. Именно Аристотель отделяет свободного человека от раба на основании наличия рассудка: «Ведь раб по природе - тот, кто может принадлежать другому (потому он и принадлежит другому) и кто причастен к рассудку в такой мере, что способен понимать его приказания, но сам рассудком не обладает» [Аристотель 2010, 39]. Таким образом, человек, способный мыслить логически, имеющий целью благо и справедливость, то есть действующий на пользу себе и другим, может управлять собой и другими, то есть властвовать. Рациональность, понимаемая в данном случае как действия в соответствии с правилами рассудка, позволяет человеку быть существом политическим как в военное, так и в мирное время. Рациональность приводит человека к успеху в достижении своих целей, в том числе и в войне, которая представляет собой рациональную деятельность. Отъем имущества у убитых врагов, взятие пленных для выполнения тяжелой работы, вытеснение противника с полезной территории - все это можно определить как рациональные действия, имеющие целью получение благ. Война стала одним из рациональных способов решения имеющихся проблем, таких как удовлетворение естественных потребностей, создание безопасной среды жизнедеятельности.

Война - целенаправленная деятельность. Победа в войне - цель всех войн. Достижение военной победы связано, прежде всего, с победой над вооруженными силами противника. Однако достижение данной цели войны не всегда приводит автоматически к достижению удовлетворяющего победителя мира. Конечной целью войны является удобный для победителя мир. В противном случае война продолжится, проигравший должен будет или признать свое поражение, или погибнуть вместе с последним солдатом. Последнее обстоятельство подводит к мысли, что между военной победой и удовлетворительным мирным договором все же есть необходимая связь, но, 
в отличие от теории, практика подтверждает это не всегда, так как в реальности существует множество условий и факторов, способных помешать осуществлению такой жесткой детерминации. Обе стороны конфликта, как правило, не стремятся к тотальному уничтожению друг друга и разумно оценивают свои шансы на успех в достижении цели. Исходя из реальных возможностей участников, из имеющихся в их распоряжении средств ставятся и цели, к которым стремятся воюющие.

Средства достижения целей войны можно разделить на материальные и идеальные. К первым относятся вооружение, ресурсная база, условия местности, в которой ведется война, численность солдат и населения страны в целом и т. д. К идеальным средствам военная стратегия, тактическая подготовка вооруженных сил, моральная стойкость солдат, способность мыслить гибко, творчески, адекватно оперативной обстановке. Использование средств на войне должно соответствовать критерию эффективности, то есть победа должна быть достигнута с наименьшими затратами материальных и идеальных ресурсов. Это в полной мере соответствует критерию рациональности, предполагающей, что эффективность достижения результата может быть воплощена в его материальной ценности и значимости.

Уже во времена Древнего мира существовал обычай не убивать пленников, не тратить на них стрел и копий, но захватывать их в рабство для того, чтобы они принесли пользу. К. Клаузевиц обращает внимание, что на войне нужно прилагать столько усилий, сколько достаточно для победы и не более того, несмотря на то что война - это деятельность, которая требует максимальных усилий и напряжения от противоборствующих сторон. М. ван Кревельд говорит о том, что осадные войны XVIII столетия в Европе часто завершались без пролития крови, но на основании расчетов, сделанных полководцами с двух сторон: «Во времена Вобана, Кохорна и их коллег осадная война достигла такого развития, что использовались научные методы применения артиллерии. Если снабжение осаждающих провиантом и боеприпасами было хорошо отлажено, то можно было с большой вероятностью предречь исход дела. И атакующая, и защищающаяся стороны могли довольно точно просчитать время операции. Стало обычной практикой сторонам договориться, что, если “подмога" не прибудет в течение определенного времени, гарнизон сложит оружие» [Кревельд 2005, 114-115].

С течением времени война начала обретать черты социального института - особым образом организованного вида деятельности, направленного на достижение конкретного результата. Воюющие стали формировать правила, нормы, передавать традиции и обычаи, выстраивать иерархию статусов и, наконец, принимать законы в отношении комбатантов, некомбатантов, оружия, памятников культуры. Все это делало войну максимально рационализированным феноменом, что во многом отражало ее гносеологические основания. Возникает феномен военной бюрократии, выражающийся в расширении численности командного состава и штабов, занимающихся войной «на бумаге»: созданием красивых планов, сложных схем, множества приказов, доведением всего этого до войск и установления контроля над их соблюдением.

Уже античные философы понимали, что для ведения войны необходимо искусное владение оружием. Античная рациональность, достигшая своего расцвета в классическую эпоху, рассматривала войну как естественное событие. Гераклит полагал, что война - первооснова всего существующего. Платон опасался войны, как начала неопределенного; он полагал, что война должна служить метафизической идее блага и считал, что ею целесообразнее заниматься особым людям в государстве с целью его защиты. Аристотель полагал, что благо воплощено в реально существующем греческом государстве-полисе, в его экономическом процветании. Войну он рассматривал как вид хозяйственной деятельности, который также должен служить идее высшего блага. Античная рациональность нашла свое отражение и в тактическом применении войск. Греки создали практически неразрушимый боевой порядок воинов - фалангу. Будучи оборонительной по своему замыслу, фаланга фактически не имела слабых мест и была идеальным построением своего времени, гарантирующим победу даже над организованным противником. Создание фа- 
ланги стало воплощением идей, свойственных рациональности. Во-первых, в ней нашли применение математика и логика. Во-вторых, была осуществлена попытка создать абсолютную и неизменную структуру, необходимо приводящую к победе над любым противником, вне зависимости от влияния субъекта, то есть объективно действующую. Похожие идеи были положены в основание римского легиона - с той разницей, что он был более гибким и мог применяться различным образом в зависимости от типа местности.

Античные мыслители видели в войнах средство, используемое человеком, но подчиненное высшей идее блага, отождествляемое с разумом и целесообразностью. В Средние века войны также были подчинены метафизическому началу: считалось, что они ведутся по замыслу Бога, который посылает одним испытания, а другим наказание за грехи. Каждый человек обладает свободной волей и разумом, способностью различать добро и зло. Делая выбор в пользу истинной веры, человек способен защищать религиозные ценности с оружием в руках. Также важны этические ценности, требующие защищать тех, на кого несправедливо напали, слабых, несчастных. Рыцарская конница, борющаяся за идеалы и интересы христиан, долгое время была символом нерушимой длани Господней. Считалось, что Бог благоволит христианам и обеспечит им победу, если они сражаются за справедливость и не увлекаются жестокостью.

В Новое время Н. Макиавелли в трактате «О военном искусстве» утверждал: «Пример древних показывает, что во всякой стране хорошие солдаты создаются обучением. Там, где не хватает природных данных, они восполняются искусством, которое в этом случае сильнее самой природы» [Макиавелли 1939,40$]$. Таким образом, война - это не просто столкновение в бою масс людей, где побеждают численность или грубая сила; важнейшим фактором становится умение, высокий профессионализм, знание военного дела. В другом месте своего трактата Н. Макиавелли утверждал: «Все ошибки в других областях можно как-нибудь исправить, но ошибки на войне не исправимы, ибо караются немедленно. Наконец, владение искусством меча рождает отвагу, так как никто не боит- ся идти на дело, к которому он подготовлен. Поэтому древние требовали от своих граждан постоянных занятий военными упражнениями и заставляли их метать в кол дротик и тяжелее настоящих; это упражнение развивало меткость удара, укрепляло мышцы и силу рук» [Макиавелли 1939, 70].

Идеи классической рациональности, воплощенные в механистической картине мира Нового времени, отразились как в способах ведения войны, так и в представлениях о самих военных действиях. Нововведения не могли не коснуться армии. Эталоном рациональной организации стала прусская армия Фридриха II, которая была педантично дисциплинирована, обучена строевой подготовке, безупречно владела огнестрельным оружием, что превращало ее в нечто подобное механизму. Уставом было предусмотрено, сколько шагов в минуту должен проходить солдат в строю, сколько выстрелов в минуту он может произвести. Боевой дух ковался муштрой, которая должна была превратить солдата в послушный винтик большого механизма.

Несколько иной, но также отвечающий принципам рациональности подход использовал А.В. Суворов, сочетавший рассыпной строй с действиями пехоты в колоннах. По сути, солдаты строились либо в прямые линии для эффективного ведения огня, либо в прямоугольники для концентрированного удара и прорыва линий противника. Идею атаки большими колоннами с одновременной концентрацией артиллерии на одном из участков поля сражения развил Наполеон I. Боевой дух и личные качества солдат и младших офицеров в расчет почти не брались. Солдат использовали как живой механический молот, силой разбивающий препятствие из других солдат.

Таким образом, субъективные качества, как и предполагается канонами классической рациональности, не учитывались. На первом месте на поле битвы были объективные факторы: резервы, число орудий, удобная позиция на местности, концентрация - то, что просчитывается, исчисляется, выстраивается в стройную логическую систему обоснованности наступления или отступления. Победа представлялась результатом объективных, рационально и эффективно использованных причин. А.В. Суворов в своей работе «Наука 
побеждать» писал о трех воинских искусствах: «Первое - глазомер: как в лагерь стать, как идти, где атаковать, гнать и бить. Втоpoe - быстрота. Третье - натиск» [Суворов 2017, 45-46]. По сути: математический расчет, скорость движения, оказание физического давления. Исходя из этого, как в сухопутных, так и в морских сражениях применялась шаблонная линейная тактика. В духе классической рациональности линейная тактика считалась универсальной и фундаментальной, охватывающей все виды войн. Развивалось и вооружение, главную роль в разработке образцов которого играли ученые-инженеры. По мере того как огнестрельное оружие вытесняло холодное, на развитие военного дела оказывали все более значительное влияние механика и математика.

Таким образом, война является не просто социальным феноменом, а предельно рационализированной, просчитанной и выверенной совокупностью последовательных действий и отношений, в которой нашли отражение способность человека формировать абстрактные понятия, мыслить рационально и доказательно. Со временем специфика войны как рациональной практики, широко использующей прогнозирование и калькуляцию, становится предметом специального исследования и изучения. Возникает то, что называют военной теорией - система руководящих идей в области военного дела, совокупность знаний о войне и армии. Карл фон Клаузевиц в своей работе «О войне» следующим образом рассуждает о сущности военной теории: «Если теория исследует предметы, составляющие сущность войны, если она более отчетливо различит то, что на первый взгляд кажется слившимся, если она укажет с достаточной полнотой все свойства средств и предусмотрит вероятные результаты их действия, если она ясно определит природу целей и осветит разумной критикой всю область войны, то она этим выполнит существеннейшую часть своей задачи» [Клаузевиц 1994, 134]. Вместе с тем К. Клаузевиц видит множество трудностей для создания подлинной военной теории. Эти трудности он описывает в духе господствующего механицизма, используя понятия трения, силы, неопределенности, маневренности, машины. Одна из таких трудностей в том, что чем больше армия, тем ею сложнее управлять, так как на выполнение приказа уходит больше времени, что приводит к снижению маневренности. Кроме того, сложноорганизованные армии были подобны механизмам, так что поломка или проблемы в одних частях могут вызвать проблемы в других частях и породить цепную реакцию. В результате возникает эффект «трения», что может привести к остановке всего военного механизма. Немаловажное влияние на итог сражения оказывают гибкость ума, способность принимать верные решения в меняющихся условиях; между тем их довольно непросто измерить и рассчитать в теории. Еще одним препятствием на пути формирования теории войны является то обстоятельство, что война ведется между разумными субъектами, оказывающими изощренное сопротивление, силу которого также трудно рассчитать. Если одна сторона примерно знает свои способности к сопротивлению, то знание о противнике всегда лишь приблизительно. Так, невозможно в оценке противника полностью положиться лишь на данные разведки, которые редко бывают полными и точными. Таким образом, неопределенность в войне («туман войны») не допускает создания «рецепта победы». Данные о противнике почти всегда не до конца достоверны, тем более что противник также стремится ввести противоборствующую сторону в заблуждение относительно своей численности, степени подготовленности войск, тактических и стратегических планов и намерений.

Обратим внимание, что в своем исследовании войны Клаузевиц не ограничивается анализом материальных факторов, то есть количеством вооружения, войск, их снаряжением, снабжением и т. п., но обращает внимание на моральный фактор, являющийся немаловажным в достижении победы, но вместе с тем трудноизмеримым и непостоянным. Мужество солдат, их боевой дух, стремление к победе могут колебаться в зависимости от множества неподдающихся калькуляции факторов. Например, одни люди в условиях опасности и риска для жизни способны действовать разумно и хладнокровно, а другие становятся рассеянными, медлительными, нерешительными. Однако, несмотря на эти трудности, построение военной теории, по мнению 
К. Клаузевица, возможно, если выделены некоторые повторяющиеся регулярности и закономерности.

Находясь, вероятно, под влиянием идей Наполеона I, К. Клаузевиц считал важнейшей стратегической целью победу в генеральном сражении. Такой подход к теории войны был отчасти опровергнут русским полководцем М.И. Кутузовым, который видел главную цель стратегии в сохранении своей армии и одновременном ослаблении армии противника. В условиях Отечественной войны 1812 г. эта асимметричная стратегия оказалась наиболее рациональным способом ведения войны. Ведя борьбу с Наполеоном I, М.И. Кутузов умело маневрировал, проводя арьергардные бои и заманивая противника вглубь страны. Он избегал генерального сражения, а затем, дав его в оборонительном стиле, продолжил умело отступать, не давая себя разбить и сохраняя костяк армии. Используя ресурсы собственной страны, русская армия получала пополнение и провиант, в то время как линии французских коммуникаций сильно растянулись и подвергались нападениям партизан. Суровые условия русской зимы, угроза голода, а также отказ русских принять поражение вынудила войска Наполеона I отступать под давлением русских войск, неся потери в мелких боях и стычках, а также во время переправ через реки. Пожалуй, именно Кутузов сумел доказать, что в войне невозможно опираться на некие универсальные объективные законы, раз и навсегда данные. Так, у армии Наполеона I было численное преимущество, отличное материально-техническое обеспечение, гениальный полководец и проверенная новая тактика. Однако поход в Россию обнаружил несостоятельность взгляда на войну как на воплощение идеалов классической рациональности: причиной поражения здесь стали иррациональные факторы - народный дух, стойкость и храбрость русского солдата, подвиг во имя Родины. Решающее влияние на результат деятельности оказала не рациональная продуманная военная стратегия и строгий расчет, а непросчитываемый субъективный фактор. По сути, не проиграв генерального сражения и взяв столицу государства, Наполеон I впервые не получил предложений о мире и вынужден был вскоре отступить - вопреки логике и разуму, ведь по всем канонам войны того времени он должен был победить. У войны, таким образом, открылось социально-психологическое измерение, непонятное «классическому» западному уму, для которого логикометодологические построения олицетворяли верный путь движения к истине (в науке) и к победе (в войне). Суровая зима, русские партизаны в тылу, удаленность от родной Франции, неразбитая русская армия и непонимание того, что делать дальше - все это планировал гениальный М.И. Кутузов, чтобы надавить на психику французских солдат и генералов, которые в итоге дрогнули.

Бурно развивающийся в XX в. технический прогресс и появление новых видов вооружений доказали, что универсальных, необходимых и неизменных законов войны не существует, что ее принципы относительны, так как развитие технического прогресса быстро превращает их в устаревшие или относительные истины. Так, теория войны продолжала активно развиваться в связи с прогрессом огнестрельного оружия и практически полным отказом от оружия холодного. В связи с этим увеличилась потребность войск в тыловом обеспечении не только продуктами питания, но и боеприпасами, без которых невозможно было вести военные действия. Вследствие этого был сделан правильный вывод о повышении роли стратегического окружения, лишавшего одну из сторон возможности сопротивляться. Германский военный теоретик Хельмут Мольтке Старший в своей теории войны перенес акцент на окружение и разгром противника в ходе внезапного нападения. Согласно Х. Мольтке, необходимо «упредить противника в проведении мобилизации и развертывании армии, внезапно начать военные действия, двигаясь к одному пункту с разных направлений, охватить противника с флангов и тем самым добиться победы в быстротечной войне» [Залесский 2011, 55]. Эта логичная теория была, вероятно, навеяна развитием естественных наук и, в частности, биологией. Если представить, что военные склады это сердце армии, а линии снабжения - ее артерии, то будет ясно, что в случае окружения армия окажется парализованной. Однако теория, созданная когда-то немецким военным теоретиком А. Шлиффеном и примененная на 
практике немцами в войне против СССР, не показала должной эффективности. Она вновь не учитывала роли субъекта, а именно - моральный дух бойцов Красной Армии, которые не спешили сдаваться в плен после окружения и продолжали вести бои без материально-технического обеспечения, приковывая к себе крупные силы противника и мешая ему быстро продвигаться вглубь страны, срывая тем самым план молниеносной войны.

Неклассический взгляд на войну выразил К. Маркс. По его мнению, война не просто инструмент политики, как у К. Клаузевица, но следствие классовой борьбы внутри общества. Политика у К. Маркса может выражать интересы не всего общества, но только господствующего класса. Угнетение и эксплуатация внугри государства порождают войну как продолжение желания эксплуататоров увеличить свой капитал за счет других стран. Диалектико-материалистический метод позволяет понять войну как динамичный и многообразный процесс, не укладывающийся в требования классической рациональности. Классовая борьба - противоречивый антагонистический процесс, который может порождать не только захватническую империалистическую войну под предводительством господствующих классов, но и войну гражданскую, классовую, которая никак не объясняется теорией К. Клаузевица. Кроме того, в случае победы пролетариата над буржуазией можно вообще покончить с захватническими войнами и вести войны освободительные, прогрессивные, под предводительством свободных трудящихся, за освобождение пролетариев других стран.

Философия марксизма оказала существенное влияние на военную мысль в СССР. Применение этой теории на практике выражалось в большом внимании, уделявшемся в Красной и Советской Армии не только развитию техники и вооружений, но и воспитательной работе с личным составом, от которого требовался высочайший уровень самоотдачи и самопожертвования ради победы коммунистических идей. Высокий моральный дух, учет субъективного фактора в Советской Армии были важнейшими преимуществами, позволявшими ей побеждать в сложнейших ситуациях, требующих максимальной выдержки от солдат, как например, в битвах под Москвой и Сталинградом. Изучение духовного опыта войны и процесса закалки духа выходило за рамки требований классической рациональности, обращавшей внимание на материальную сторону социальных феноменов.

В данном случае следует указать на интересный и значимый для данного исследования факт. Для русских мыслителей, в том числе и теоретиков войны, традиционным и предпочтительным было обращение к греческим, а не к латинским текстам, что позволяло избегать чистого гносеологизма, «зрить в корень», в суть и сущность проблемы, то есть видеть и фиксировать онтологическую обусловленность проблем и явлений [Леонтьева 2003]. «По своей сущности, война и есть приложение в жизни человеческих обществ всемирного закона борьбы за существование, определяющего жизнь и развитие всего органического мира» [Величко 1912, 8].

Вторая мировая война проходила в эпоху утверждения неклассической рациональности, признававшей решающую роль субъекта в познании и практике. Одними из важных составляющих этой войны были попытки оказать мощное психологическое воздействие на психику субъектов войны посредством пропаганды, продуманных приемов организации паники, создания атмосферы страха в тылу врага. После окончания Второй мировой войны и появления ядерного оружия теория войны вновь претерпела изменения. Применение ядерного оружия обнулило все прежние достижения и принципы.

В дальнейшем теория непрямых действий английского теоретика Б. Лиддел Гарта, который утверждал необходимость не физического, а, прежде всего, психологического давления на противника, суть которого он свел к понятию «непрямого действия» [Лиддел Гарт 2003, 23], получила свое продолжение. На практике объектами нападения становятся средства коммуникации и снабжения, счета в банках, организуется дискредитация правительства противника в СМИ и проч. Главная цель - психика человека, а не его физическое уничтожение. Также возникает так называемая теория управляемого хаоса, опирающаяся на ключевые идеи синергетики центральной теории постнеклассической рациональности. В своей работе «Порядок из 
хаоса. Новый диалог человека с природой» И. Пригожин и И. Стенгерс высказали идею о позитивной роли хаоса в физических процесcax [Пригожин 1986, 236]. Разрушение системы приводит одновременно к открытию возможностей для ее трансформации.

Опирающиеся на эту теорию подходы получили распространение в военной мысли и в новой стратегии, применяемой на практике. Общественные системы сопротивляются воздействию извне. Внешнее воздействие всегда вызывает ответное противодействие. Исходя из этого военное вмешательство всегда чревато ответной агрессией. Оккупация территории приводит к расходу сил и постоянной борьбе с завоеванным населением. Теория управляемого хаоса предполагает, что гораздо более эффективным способом навязать свою волю противнику является не применение открытой агрессии, но альтернативный путь поддержания социальной системы тех сил, которые дестабилизируют власть, критикуют официальный политический курс, идеологию и способствуют нарастанию хаоса. В этом случае ослабляются культурные связи внутри страны, выкачиваются финансовые средства, подрывается наука, разрушается производство, усиливается коррупция, снижается численность населения и проч. Так как деструктивные оппозиционные силы являются частью самой системы, последняя не воспринимает их как нечто чужеродное и не сопротивляется им активно. По сути, так называемая «холодная война» была реализацией теории управляемого хаоса. Другими примерами могут быть Ливия, Сирия, Египет и Украина. В этих странах помимо мирного сценария был осуществлен и классический военный сценарий с переходом к гражданской войне. В России была применена так называемая гибридная война, в которой использовались методы диверсионной войны с участием террористов, бандитов и наемников в комбинации с обычной, традиционной войной. Таким образом, сформировалась концепция так называемой неклассической войны, под которой подразумевают ассиметричные конфликты с партизанскими или гибридными вооруженными силами. Некоторые теоретики вообще считают вооруженное насилие в современности «анахронизмом» [Kaldor 2001, 71].
На стыке военной и невоенной областей знаний возникает информационная теория войны, которая понимается двояко. С одной стороны, под информационной войной понимают борьбу с применением невоенных средств, направленных на манипуляцию сознанием, атаки на программное обеспечение и т. д. Сторонники другого подхода рассматривают развитие информатизации как путь к созданию более эффективного оружия, новых управляющих систем, беспилотных аппаратов, а также возможности объединения всех видов войск и вооружений в единую сеть, способную мгновенно реагировать на любое изменение боевой обстановки за счет создания единого информационного поля боя. Последняя концепция называется еще сетецентрической и, по мнению авторов статьи, является наиболее прогрессивной военной теорией настоящего и ближайшего будущего. Сетецентрическая война применяет принцип самоорганизации в области управления войсками. Благодаря развитию информационных технологий атакующие или обороняющиеся части передают друг другу информацию о происходящих событиях, создавая для всех общую картину боя в режиме реального времени. В результате каждая боевая единица способна реагировать и принимать решения самостоятельно, без согласования со штабом, то есть организуя бой практически без внешнего вмешательства.

Таким образом, война в качестве самого конкурентного вида человеческой борьбы не только стимулирует использование в военной теории и практике последних достижений всех отраслей научного и технического знания, но и отражает в своей эволюции изменение типов и норм рациональности.

\section{СПИСОК ЛИТЕРАТУРЫ}

Августин Блаженный 1998 - Блаженный Августин. Творения в 4 т. Т. 4. О граде Божием. Кн. 14 22. СПб.: Алетейя; Киев: УЦИММ-Пресс, 1998.

Аристотель 2010 - Аристотель. Политика. М.: [б. и.], 2010.

Величко 1912 - Величко К.И. Военная энциклопедия. Петербург: Тип. Т-ва И.Д. Сытина, 1912.

Гегель 1990 - Гегель Г.Ф.В. Философия права: пер. с нем. / ред. и сост. Д.А. Керимов, В.С. Нерсесянц. М.: Мысль, 1990. 
Герасимов 2019 - Герасимов Н.Н. Философский анализ образа войны в эпоху глобализации: дис. ... канд. филос. наук: 09.00.11. Волгоград, 2019.

Гроций 1994 - Гроциии Г. О праве войны и мира. М.: Ладомир, 1994.

Гулевский, Гулевская 2012 - Гулевский А.Н., Гулевская Н.А. Онтологические основания войны // Известия ВолгГТУ. Серия: Проблемы социально-гуманитарного знания. 2012. Вып. 11. № 8 (95). С. 16-19.

Гулевский 2014 - Гулевский А.Н. Антропология войны: воля к битве // Известия ВолгГТУ. Серия: Проблемы социально-гуманитарного знания. 2014. Вып. 16. № 5(132). С. 9-12.

Гулевский, Гулевская , Доронин 2018 - Гулевский А.Н., Гулевская Н.А., Доронин Ю.П. Об основаниях войны в социальном бытии // Философия права. 2018. № 3 (86). С. 69-76.

Залесский 2011 - Залесский К.А. Военная элита Германии. 1870-1945: энциклоп. справ. М.: Вече, 2011.

Ильин 2014 - Ильин И.А. О сопротивлении злу силой. М.: ДАРЬ, 2014.

Кант 1966 - Кант И. Сочинения в 6 т. Т. 6. М.: Мысль, 1966.

Клаузевиц 1994 - Клаузевии К. О войне. М.: Логос; Наука, 1994.

Кокошин 2016 - Кокошин А.А.Несколько измерений войны. Вопросы философии. 2016. № 8. С. 5-19.

Кревельд 2005 - Кревельд М. ван. Трансформация войны. М.: Альпина Бизнес букс, 2005.

Леонтьева 2003 - Леонтьева Е.Ю. Рациональность и ее типы: генезис и эволюция: автореф. дис. ... д-ра филос. наук: 09.00.01. Ростов н/Д, 2003.

Лиддел Гарт 2003 - Лиддел Гарт Б. Энциклопедия военного искусства. М.: АСТ, 2003.

Макиавелли 1939 - Макиавелли Н. О военном искусстве. М.: Гос. воен. изд-во Наркомата обороны Союза ССР, 1939.

Ницше 2005 - Ницще Ф. Воля к власти. М.: Культ. революция, 2005.

Перкинс 2012 - Перкинс Д. Исповедь экономического убийцы. М.: Претекст, 2012.

Платон 1994 - Платон. Собрание сочинений в 4 т. Т. 3. М.: Мысль, 1994.

Попов, Хамзатов 2016 - Попов И.М., Хамзатов М.М. Война будущего: Концептуальные основы и практические выводы. Очерки стратегической мысли. М.: Кучково поле, 2016.

Пригожин, Стенгерс 1986 - Пригожин И., Стенгерс И. Порядок из хаоса: Новый диалог человека с природой. М.: Прогресс, 1986.

Снесарев 2013 - Снесарев А.Е. Философия войны. М.: Ломоносов, 2013.

Соловьев 2011 - Соловьев В. Три разговора о войне, прогрессе и конце всемирной истории. Вели- кий спор и христианская политика. М.: Ин-т рус. цивилизации: Алгоритм, 2011.

Суворов 2017 - Суворов А.В. Наука побеждать. М.: ACT, 2017.

Сунь-цзы 2010 - Сунь-изыл. Искусство войны. Основы китайской военной стратегии. СПб.: ДИЛЯ, 2010.

Тоффлер 2005 - Тоффлер Э. Война и антивойна. М.: АСТ: Транзиткнига, 2005.

Хейзинга 2011 - Хейзинга Й. Homo ludens. Человек играющий / сост., предисл. и пер. с нидерл. Д.В. Сильвестрова; коммент. указатель Д.Э. Харитоновича. СПб.: Изд-во Ивана Лимбаха, 2011.

Хоркхаймер, Адорно 1997 - Хоркхаймер М., Адорно T. Диалектика Просвещения. Философские фрагменты. М.; СПб.: [б. и.], 1997.

Хофмайстер 2006 - Хофмайстер X. Воля к войне, или бессилие политики. СПб.: Гуманит. академия, 2006.

Kaldor 2001 - Kaldor M. New and Old Wars: Organized Violence in a Global Era: With an Afterword. Stanford: Stanford University Press, 2001.

\section{REFERENCES}

Augustine Blessed, 1998. Creations in 4 vols. Vol. 4. About the God's Hail. Books 14-22. Saint Petersburg, Aleteya Publ.; Kiev, UKIMM-Press Publ.

Aristotle, 2010. Policy. Moscow.

Velichko K.I., 1912. Military Encyclopedia. Petersburg, Printing house T-va I.D. Sytin.

Hegel G.F.V., 1990. Philosophy of Law. Moscow, Mysl Publ.

Gerasimov N.N., 2019. Philosophical Analysis of the Image of War in the Era of Globalization. Cand. philos. sci. abs. diss. Volgograd.

Grotius G., 1994. On the Law of War and Peace. Moscow, Ladomir Publ.

Gulevsky A.N., Gulevsky N.A., 2012. Ontological Grounds of War. Izvestiya VolgGTU. Series: Problems of Social and Humanitarian Knowledge, iss. 11, no. 8 (95), pp. 16-19.

Gulevsky A.N., Gulevsky N.A., Doronin Yu.P., 2018. On the Grounds of War in Social Being. Philosophy of Law, no. 3 (86), pp. 69-76.

Zalessky, K.A., 2011. Germany's Military Elite. 18701945. Encyclopedia Handbook. Moscow, Veche Publ.

Ilyin I.A., 2014. On Resisting Evil by Force. Moscow, DAR Publ.

Kant I., 1966. Writings in 6 vols. Vol. 6. Moscow, Mys1 Publ.

Clausewitz K., 1994. On the War. Moscow, Logos Publ., Nauka Publ.

Kokoshin A.A., 2016. New Dimensions of War. Philosophy Questions, no. 8, pp. 5-19. 
Creveld M. van., 2005. Transformation of War. Moscow, Alpina Biznes Buks Publ.

Leontieva E.Y., 2003. Rationality and Its Types: Genesis and Evolution. Dr. philos. sci. abs. diss. Rostov-on-Don.

Liddel Garth B., 2003. Encyclopedia of Military Art. Moscow, AST Publ.

Machiavelli N., 1939. On Military Art. Moscow, Gos. voen. izd-vo Narkomata oborony Soyuza SSR Publ.

Nietzsche F., 2005. Vola to power. Moscow, Kult. revolutsiya Publ.

Perkins D., 2012. Confession of Economic Killer. Moscow, Pretekst Publ.

Plato, 1994. Collected Works in 4 vols. Vol. 3. Moscow, Mysl Publ.

Popov I.M., Hamzatov M.M., 2016. War of the Future: Conceptual Foundations and Practical Conclusions. Sketches of a Strategic Thought. Moscow, Kuchkovo pole Publ.

Prigozhin I., Stengers I., 1986. Order from Chaos: A New Human Dialogue with Nature. Moscow, Progress Publ.
Snesarev A.E., 2013. Philosophy of War. Moscow, Lomonosov Publ.

Soloviev V., 2011. Three Conversations About War, Progress and the End of World History. Great Dispute and Christian Politics. Moscow, Institute of Russian Civilization, Algorithm Publ.

Suvorov A.V., 2017. Science to Win. Moscow, AST Publ.

Sun Tzu, 2010. Art of War. Fundamentals of Chinese Military Strategy. Saint Petersburg, DILYA Publ.

Toffler E., 2005. War and Anti-War. Moscow, AST Publ., Tranzitkniga Publ.

Heising J., 2011. Homo Ludens. The Man Playing. Saint Petersburg, Ivan Limbach Publ.

Horkheimer M., Adorno T., 1997. Dialectic Enlightenment. Philosophical Fragments. Moscow; Saint Petersburg.

Hofmeister H., 2006. Will to War, or Impotence of Politics. Saint Petersburg, Gumanit. akademiya.

Kaldor M., 2001. New and Old Wars: Organized Violence in a Global Era: With an Afterword. Stanford, Stanford University Press.

\section{Information About the Authors}

Alexey N. Gulevsky, Candidate of Sciences (Philosophy), Associate Professor, Department of Philosophy, Volgograd Academy of the Ministry of Internal Affairs of the Russian Federation, Istoricheskaya St, 130, 400089 Volgograd, Russian Federation, gulewski@yandex.ru, https://orcid.org/0000-0002-6356-6605

Yuri P. Doronin, Candidate of Sciences (History), Associate Professor, Senior Lecturer, Department of Philosophy, Volgograd Academy of the Ministry of Internal Affairs of the Russian Federation, Istoricheskaya St, 130, 400089 Volgograd, Russian Federation, dup3000@yandex.ru, https://orcid.org/0000-0001-8753-0730

\section{Информация об авторах}

Алексей Николаевич Гулевский, кандидат философских наук, доцент кафедры философии, Волгоградская академия МВД России, ул. Историческая, 130, 400089 г. Волгоград, Российская Федерация, gulewski@yandex.ru, https://orcid.org/0000-0002-6356-6605

Юрий Петрович Доронин, кандидат исторических наук, доцент, старший преподаватель кафедры философии, Волгоградская академия МВД России, ул. Историческая, 130, 400089 г. Волгоград, Российская Федерация, dup3000@yandex.ru, https://orcid.org/0000-0001-8753-0730 